\title{
PENGARUH KARAKTER DEBITUR DAN PENDAPATAN NASABAH TERHADAP KOLEKTIBILITAS PADA BMT AL-MUQRIN
}

\author{
Sri Retnaning Sampurnaningsih \\ Universitas Pamulang, Tangerang Selatan, Banten, Indonesia \\ dosen01366@unpam.ac.id
}

\begin{abstract}
Abstrak
Penelitian ini bertujuan untuk mengetahui pengaruh karakter debitur dan pendapatan nasabah terhadap kolektibilitas pada BMT Al-Muqrin. Metode yang digunakan adalah explanatory research dengan teknik analisis menggunakan analisis statistik dengan pengujian regresi, korelasi, determinasi dan uji hipotesis. Hasil penelitian ini karakter debitur berpengaruh signifikan terhadap kolektibilitas sebesar 43,4\%, uji hipotesis diperoleh thitung $>\mathrm{t}$ tabel atau $(8,449>1,986)$. Pendapatan nasabah berpengaruh signifikan terhadap kolektibilitas sebesar 49,3\%, uji hipotesis diperoleh $t$ hitung $>t$ tabel atau $(8,595>1,986)$. Karakter debitur dan pendapatan nasabah secara simultan berpengaruh signifikan terhadap kolektibilitas dengan persamaan regresi $\mathrm{Y}=13,633+0,338 \mathrm{X} 1+0,526 \mathrm{X} 2$ dan kontribusi pengaruh sebesar 55,2\%, uji hipotesis diperoleh $F$ hitung $>\mathrm{F}$ tabel atau $(56,629>2,700)$.
\end{abstract}

Kata Kunci: Karakter Debitur, Pendapatan Nasabah, Kolektibilitas.

\begin{abstract}
This study aims to determine the effect of debtor character and customer income on collectibility at BMT Al-Muqrin. The method used is explanatory research with analytical techniques using statistical analysis with regression, correlation, determination and hypothesis testing. The results of this study indicate that the debtor's character has a significant effect on collectibility by $43.4 \%$, hypothesis testing is obtained t count $>$ t table or (8.449 > 1.986). Customer income has a significant effect on collectibility by $49.3 \%$, hypothesis testing is obtained $t$ count $>t$ table or $(8,595>1,986)$. Debtor character and customer income simultaneously have a significant effect on collectibility with the regression equation $Y=13.633+0.338 X 1+0.526 X 2$ and the contribution of the influence is 55.2\%, hypothesis testing is obtained F count $>$ F table or (56.629 $>2,700$ ).
\end{abstract}

Keywords: debtor character, customer income, collectibility.

\section{PENDAHULUAN}

Lahirnya bank syariah pertama di indonesia yaitu Bank Muamalat Indonesia, sebelum lahirnya undang-undang yang memungkinkan pendirian bank yang sepenuhnya melakukan kegiatan yang berdasarkan prinsip syariah. Bank Muamalat Indonesia lahir pada tahun 1991 sebelum di undangkannya undang- undang tentang perbankan yang baru, yaitu UndangUndang No. 7 tahun 1992. Berdasarkan Undang-undang No. 7 tahun 1992 itu, dimungkinkan bagi bank untuk melakukan kegiatan usahanya bukan berdasarkan bunga tetapi berdasarkan bagi hasil. Untuk mengembangkan perbankan syariah di indonesia, pengembangan sistem perbankan syariah di Indonesia yang dilakukan oleh bank indonesia adalah dalam kerangka dualbanking system (sistem perbankan ganda) dalam kerangka Arsitektur Perbankan Indonesia (API) dengan tujuan untuk menghadirkan jasa perbankan alternatif bagi masyarakat indonesia yang pada kenyataannya sebagian besar adalah orang muslim, diharapkan agar sistem perbankan syariah dan perbankan konvensional secara sinergis dapat mendukung mobilisasi dana masyarakat secara lebih luas untuk meningkatkan kemampuan perbankan memberikan pembiayaan bagi sektor-sektor perekonomian nasional.

Dengan berkembangnya perbankan syariah di Indonesia, mendorong berkembangnya lembaga keuangan syariah lainnya seperti asuransi syariah, lembaga pembiayaan syariah, pegadaian syariah, koperasi syariah, dan juga lembaga keuangan mikro syariah yang sering disebut dengan Baitul Maal wat Tamwil (BMT). BMT merupakan lembaga keuangan mikro yang berbadan hukum Koperasi Syariah atau Koperasi Jasa Keuangan Syariah atau Koperasi Jasa Keuangan Syariah ( KJKS ). 
Lembaga keuangan syariah tersebut mempunyai karakteristik umum dan landasan dasar operasional secara keseluruhan sesuai dengan prinsip syariah yaitu prinsip bagi hasil (profit sharing).

Salah satu perwujudan dari sistem lembaga keuangan mikro syariah yaitu Baitul maal wat tamwil (BMT). BMT terdiri dari dua istilah, yaitu baitul maal dan baitut tamwil. Baitul maal lebih mengarah pada usaha-usaha pengumpulan dan penyaluran dana yang non profit. Sedangkan baitut tamwil sebagai usaha pengumpulan dan penyaluran dana komersial. Usaha-usaha tersebut menjadi bagian yang tidak terpisahkan dari BMT sebagai lembaga pendukung kegiatan ekonomi masyarakat kecil dengan berlandaskan syariah. BMT bersifat terbuka, independen, berorientasi pada pengembangan tabungan dan pembiayaan untuk mendukung bisnis ekonomi yang produktif bagi anggota dan kesejahteraan sosial masyarakat sekitar, terutama usaha mikro dan fakir miskin. Peran BMT dalam kondisi saat sekarang ini sangat di butuhkan sekali, karena maraknya rentenir di tengah-tengah masyarakat mengakibatkan masyarakat semakin terjerumus pada masalah ekonomi yang tidak menentu. Besarnya pengaruh rentenir terhadap perekonomian masyarakat tidak lain karena tidak adanya unsur- unsur yang cukup akomodatif dalam menyelesaikan masalah yang masyarakat hadapi. Oleh karena itu, BMT diharapkan mampu berperan lebih aktif dalam memperbaiki kondisi ini. Dalam menjalankan usahanya, BMT mempunyai lima konsep dasar yang terdiri dari sistem simpanan murni ( $A l$ Wadiah, Al Mudharabah), sistem bagi hasil (Al Mudharabah - Al Musyarakah), sistem jual beli dan margin keuntungan ( $B a i$ ' $A l$ Murabahah, Bai 'Bitsaman Ajil, Bai 'As Salam, Dan Bai 'Al Istishna), sistem non profit dan produk pembiayaan dengan pengembalian fee (Al Kafalah, Al Hiwalah, Al Jialah, Dan Al Wakalah).

Penyaluran pembiayaan oleh BMT salah satunya digunakan untuk membantu nasabahnya yang membutuhkan dana sehingga ketika nasabah mendapatkan bantuan pembiayaan maka diharapkan nasabah yang telah diberikan pembiayaan berkewajiban untuk mengembalikan pembiayaan secara penuh agar tidak terjadi kelalaian dan rusaknya moral seseorang disebabkan karena kurangnya kesadaran bahwasanya dia telah dibantu sedangkan dia sengaja tidak mengembalikannya. Apabila hal tersebut terjadi, akan menimbulkan pembiayaan bermasalah yang jika tidak segera ditindak lanjuti menyebabkan kerugian terhadap lembaga keuangan yang berimbas pada kesehatan BMT.

Pembiayaan Murabahah merupakan jual beli barang pada harga asal dengan tambahan keuntungan yang disepakati dan pihak BMT harus memberitahu harga barang yang dibeli dan memberitahukan harga jual barang kepada anggota. Berikut adalah grafik perkembangan pembiayaan di BMT Al-Muqrin.

Pembiayaan Murabahah yang diberikan tidak akan lepas dari resiko terjadinya pembiayaan bermasalah seperti penunggakan bahkan kemacetan pembayaran angsuran. Semakin banyak pembiayaan yang di berikan akan berpengaruh terhadap profitabilitas BMT dan memungkinkan resiko keredit macet akan meningkat. Selain itu terhambatnya pengembalian pembiayaan yang diberikan BMT dapat menurunkan tingkat likuiditas, solvabilitas, dan rentabilitas BMT sendiri yang pada akhirnya menyebabkan lemahnya kemampuan BMT dalam membayar kewajibannya dan menghambat sirkulasi uang yang dapat menurunkan profitabilitas BMT. Dalam pemberian pembiayaan, BMT memerlukan adanya analisis pembiayaan kepada calon anggota. Analisis pembiayaan memiliki tujuan untuk menilai kelayakan calon anggota. Jika terjadi kelalaian atau kesalahan dalam menganalisis calon anggota maka akan merugikan pihak BMT. Menurut Kasmir dapat dilihat melalui analisis pembiayaan dengan prinsip $5 \mathrm{C}$ yaitu character, capacity, conditions, collateral, capital.

Salah satu keberhasilan dalam pemberian pembiayaan sangat tergantung pada tingkat kejujuran maupun itikad baik dari debitur. Penilaian watak ini merupakan pekerjaan yang sangat sulit, karena dari pihak debitur akan berusaha untuk selalu terkesan baik. Oleh karena itu, dalam melakukan penilaian watak diperlukan adanya suatu strategi, metode ataupun 
keahlian dalam mengenali watak debitur sehingga dapat memperoleh gambaran yang sesungguhnya. Salah satunya yaitu dengan menilai keperibadian (Personality), karena keperibadian merupakan faktor yang harus dinilai. Memiliki keperibadian yang baik akan mendapatkan prioritas untuk mendapatkan pembiayaan, dengan keperibadian baik tidak dipungkiri anggota tersebut mempunyai itikad baik untuk melunasi atau mengembalikan pembiayaan sehingga tidak akan menyulitkan BMT dikemudian hari. Unsur terpenting dalam pembentukan karakter adalah pikiran, karena pikiran yang di dalamnya terdapat seluruh program yang terbentuk dari pengalaman hidupnya yang merupakan pelopor segalanya.

Masyarakat di Indonesia tergolong ciri masyarakat yang konsumtif. Mereka lebih senang mengkonsumsi daripada berproduksi. Gelombang modernisasi saat ini membawa manusia pada gaya hidup yang berfoya-foya dan berhura-hura. Banyak hal yang dapat menawarkan kenikmatan duniawi, itulah yang akan dikejar dan dijadikan pedoman. Maka dalam kehidupan ini banyak manusia modern yang terjerumus dalam rangkaian kehidupan yang berkejaran dengan nafsu keinginan. Sehingga muncul pola pikir yang keliru, kebutuhan sekunder yang dijadikan kebutuhan primer, sedangkan kebutuhan primer menjadi tidak begitu diutamakan meskipun itu penting.

Sedangkan, pendapatan adalah uang yang diterima seseorang dalam bentuk gaji (wage), upah, sewa, laba dan sebagainya yang didapatkan oleh anggota secara rutin. Pendapatan (Profitability) digunakan sebagai salah satu penilaian kepada anggota untuk menganalisis bagaimana kemampuan anggota dalam mencari keuntungan usahanya. Pada realitanya ada beberapa fenomena yang terjadi murabahah itu tidak berjalan lancar yang disebabkan dari pihak nasabah itu sendiri diantaranya nasabah tidak ingin bank atau pun lembaga keuangan syariah lainnya mengetahui pendapatan nasabah ketika diinterview saat nasabah hendak mengajukan permohonan pembiayaan. Maka perlunya pihak bank atau lembaga keuangan syariah lainnya memperhatikan pendapatan nasabah tersebut berguna untuk melindungi nasabah agar nasabah tidak merasa terbebani dalam membayar angsuran. Pendapatan disini diartikan penerimaan bersih seseorang. Semakin besar pendapatan nasabah maka semakin besar pula peluang kelancaran pembayaran pembiayaan murabah terjadi.

Dalam Islam, kita diwajibkan untuk berusaha agar mendapatkan rezeki yang halal untuk memenuhi kebutuhan hidup. Seorang muslim harus memiliki semangat untuk lebih produktif sehingga mampu memberikan manfaat bagi lingkungan di sekitarnya. Seseorang yang memiliki kepribadian seperti ini akan senantiasa bekerja keras memanfaatkan keahlian dan keterampilannya pada usaha- usaha produktif. Dengan usaha dan kerja keras tersebut diharapkan akan menghasilkan pendapatan atau keuntungan dari hasil usaha menjual barang atau jasa tersebut. Pendapatan yang dimiliki dapat digunakan untuk memenuhi kebutuhan pribadi mereka atau disisihkan untuk memperluas usaha dan memenuhi kewajiban-kewajiban mereka.

Oleh sebab itu, analisis pembiayaan atas karakter debitur dan pendapatan nasabah ini sangat diperlukan untuk mengurangi resiko terjadinya pembiayaan bermasalah seperti penunggakan bahkan kemacetan pembayaran angsuran. Berkaitan dengan hal-hal tersebut diatas, maka penulis tertarik untuk memilih judul: "Pengaruh Karakter Debitur dan Pendapatan Nasabah Terhadap Tingkat Pengembalian Pembiayaan Murabahah pada BMT Al-Muqrin".

\section{TINJAUAN PUSTAKA}

\section{Karakter debitur}

Karakter merupakan sifat atau watak seseorang. Sifat atau watak seseorang yang akan diberikan kredit benar-benar harus dipercaya. Dengan demikian tidak akan terjadi kegagalan dalam dalam pemberian pembiayaan. Sedangkan debitur adalah pihak penerima hutang yang diperoleh dari pemberi hutang yang diperoleh dari pemberi hutang yang pembayarannya ditentukan oleh jangka waktu pengembalian yang sudah disepakati sebelumnya. 


\section{Pendapatan nasabah}

Menurut Kamus Bisnis Islam pendapatan atau income disebut juga dengan ratib, salary, reward yang merupakan uang yang diterima seseorang dan perusahaan dalam bentuk gaji (wage), upah, sewa, laba dan sebagainya. Menurut PSAK nomor 23 paragraf 6 , pendapatan adalah arus masuk bruto dari manfaat ekonomi yang timbul dari aktivitas normal perusahaan selama suatu periode bila arus masuk itu mengakibatkan kenaikan ekuitas yang tidak berasal dari kontribusi penanaman modal.

\section{Kolektibilitas}

Pengembalian pembiayaan (kolektibilitas) adalah gambaran kondisi pembayaran pokok dan bunga pinjaman serta tingkat kemungkinan diterimanya kembali dana yang ditanamkan dalam surat-surat berharga. Kolektibilitas merupakan keadaan pembayaran pokok atau angsuran pokok dan bunga kredit oleh anggota serta tingkat kemungkinan diterimanya kembali dana yang ditanamkan dalam surat-surat berharga atau penanaman lainnya. Dari pengertian di atas dapat disimpulkan bahwa kredit atau pembiayaan dimaksudkan untuk memperoleh keuntungan (profit), maka lembaga keuangan syariah hanya boleh meneruskan simpanan masyarakat kepada anggotanya dalam bentuk pembiayaan. Pembiayaan diberikan kepada anggota, jika pihak lembaga keuangan syariah merasa yakin bahwa anggota yang akan menerima pembiayaan mampu dan mau mengembalikan pembiayaan yang telah diterimanya beserta bagi hasil.

\section{METODE}

Populasi dalam penelitian ini berjumlah 95 responden BMT Al-Muqrin. Sampel dalam penelitian ini berjumlah 95 responden. Jenis penelitian yang dipakai adalah asosiatif, dimana tujuannya adalah untuk mengetahui pengaruh antara variabel bebas terhadap variabel terikat baik parsial maupun simultan Dalam menganalisis data digunakan uji instrumen, uji asumsi klasik, regresi, koefisien determinasi dan uji hipotesis

\section{HASIL DAN PEMBAHASAN}

\section{Analisis Deskriptif}

Pada pengujian ini digunakan untuk mengetahui skor minimum dan maksimum, mean score dan standar deviasi dari masing-masing variabel. Adapun hasilnya sebagai berikut:

Tabel 1. Hasil Analisis Descriptive Statistics

\section{Descriptive Statistics}

N Minimum Maximum Mean Std. Deviation

\begin{tabular}{|l|l|l|l|l|l|l|}
\hline Karakter Debitur (X1) & 95 & 30 & 48 & 37.84 & 4.048 \\
\hline Pendapatan Nasabah (X2) & 95 & 31 & 46 & 37.98 & 3.673 \\
\hline Kolektibilitas (Y) & 95 & 39 & 56 & 46.42 & 4.094 \\
\hline Valid N (listwise) & 95 & & & & \\
\hline
\end{tabular}

Karakter debitur diperoleh varians minimum sebesar 30 dan varians maximum 48 dengan mean score sebesar 3,78 dengan standar deviasi 4,048.

Pendapatan nasabah diperoleh varians minimum sebesar 31 dan varians maximum 46 dengan mean score sebesar 3,79 dengan standar deviasi 3,673.

Kolektibilitas diperoleh varians minimum sebesar 39 dan varians maximum 59 dengan mean score sebesar 4,64 dengan standar deviasi 4,094.

\section{Analisis Kuantitatif}

Pada analisis ini dimaksudkan untuk mengetahui pengaruh variabel independen terhadap variabel dependen baik secara parsial maupun secara simultan. Adapun hasil pengujian sebagai berikut:

\section{a. Analisis Regresi Linier Berganda}

Uji regresi ini dimaksudkan untuk mengetahui perubahan variabel dependen jika variabel independen mengalami perubahan. Adapun hasil pengujiannya sebagai berikut: 
Tabel 2. Hasil Pengujian Regresi Linier Berganda Coefficients $^{\mathbf{a}}$

Unstandardized Coefficients

\begin{tabular}{l|r|r} 
Model & \multicolumn{1}{c|}{ B } & Std. Error \\
\hline 1 (Constant) & 13.633 & 3.097 \\
\hline Karakter Debitur (X1) & .338 & .097 \\
\hline Pendapatan Nasabah (X2) & .526 & .107 \\
\hline
\end{tabular}

a. Dependent Variable: Kolektibilitas (Y)

Berdasarkan hasil pengujian pada tabel di atas, diperoleh persamaan regresi $Y=13,633+0,338 X 1+0,526 X 2$. Dari persamaan tersebut dijelaskan sebagai berikut:

1) Konstanta sebesar 13,633 diartikan jika karakter debitur dan pendapatan nasabah tidak ada, maka telah terdapat nilai kolektibilitas sebesar 13,633 point.

2) Koefisien regresi karakter debitur sebesar 0,338, angka ini positif artinya setiap ada peningkatan karakter debitur sebesar 0,338 maka kolektibilitas juga akan mengalami peningkatan sebesar 0,338 point.

Tabel 3. Hasil Pengujian Koefisien Korelasi Karakter debitur Terhadap Kolektibilitas.

Correlations $^{\mathbf{b}}$

\begin{tabular}{llr|r} 
& & Karakter debitur (X1) & Kolektibilitas (Y) \\
\hline Karakter Debitur (X1) & Pearson Correlation & 1 & $.659^{* *}$ \\
\cline { 2 - 4 } & Sig. (2-tailed) & & .000 \\
\hline Kolektibilitas (Y) & Pearson Correlation & $.659^{* *}$ & 1 \\
\cline { 2 - 4 } & Sig. (2-tailed) & .000 & \\
\hline
\end{tabular}

Berdasarkan hasil pengujian diperoleh nilai korelasi sebesar 0,659 artinya karakter debitur memiliki Tabel 4. Hasil Pengujian Koefisien Korelasi Pendapatan nasabah Terhadap Kolektibilitas. Correlations $^{\mathbf{b}}$ Pendapatan nasabah (X2) Kolektibilitas (Y)

\begin{tabular}{|c|c|c|c|}
\hline \multirow{2}{*}{ Pendapatan Nasabah (X2) } & Pearson Correlation & 1 & $.702^{* *}$ \\
\hline & Sig. (2-tailed) & & .000 \\
\hline \multirow[t]{2}{*}{ Kolektibilitas (Y) } & Pearson Correlation & $.702^{* *}$ & 1 \\
\hline & Sig. (2-tailed) & .000 & \\
\hline
\end{tabular}

Berdasarkan hasil pengujian diperoleh nilai korelasi sebesar 0,702 artinya pendapatan nasabah memiliki hubungan yang kuat terhadap kolektibilitas. dimaksudkan untuk mengetahui tingkt kekuatan hubungan dari variabel independen terhadap variabel dependen baik secara parsial maupun simultan. Adapun hasil pengujian sebagai berikut:

Tabel 5. Hasil Pengujian Koefisien Korelasi Karakter debitur dan Pendapatan nasabah secara simultan Terhadap Kolektibilitas.

Model Summary

\begin{tabular}{lr|r|r|r} 
Model & $\mathrm{R}$ & R Square & Adjusted R Square & Std. Error of the Estimate \\
\hline 1 & $.743^{\mathrm{a}}$ & .552 & .542 & 2.770 \\
\hline
\end{tabular}

a. Predictors: (Constant), Pendapatan Nasabah (X2), Karakter Debitur (X1) 
Berdasarkan hasil pengujian diperoleh nilai korelasi sebesar 0,743 artinya karakter debitur dan pendapatan nasabah secara simultan memiliki hubungan yang kuat terhadap kolektibilitas. c. Analisis Koefisien Determinasi

Analisis koefisien determinasi dimaksudkan untuk mengetahui besarnya persentase pengaruh dari variabel independen terhadap variabel dependen baik secara parsial maupun simultan. Adapun hasil pengujian sebagai berikut:

Tabel 6. Hasil Pengujian Koefisien Determinasi Karakter debitur Terhadap Kolektibilitas.

\section{Model Summary}

\begin{tabular}{cc|c|c|c} 
Model & R & R Square & Adjusted R Square & Std. Error of the Estimate \\
\hline 1 & &
\end{tabular}

\begin{tabular}{lrrrr}
\hline 1 & $.659^{\mathrm{a}}$ & .434 & .428 & 3.096 \\
\hline
\end{tabular}

a. Predictors: (Constant), Karakter Debitur (X1)

Berdasarkan hasil pengujian diperoleh nilai determinasi sebesar 0,434 artinya karakter debitur

Tabel 7. Hasil Pengujian Koefisien Determinasi Pendapatan nasabah Terhadap

\section{Kolektibilitas.}

\section{Model Summary}

\begin{tabular}{ll|l|l|l} 
Model & $\mathrm{R}$ & $\mathrm{R}$ Square & Adjusted R Square & Std. Error of the Estimate \\
\hline
\end{tabular}

\begin{tabular}{lrrrr}
\hline 1 & $.702^{\mathrm{a}}$ & .493 & .487 & 2.932 \\
\hline
\end{tabular}

a. Predictors: (Constant), Pendapatan Nasabah (X2)

Berdasarkan hasil pengujian diperoleh nilai determinasi sebesar 0,493 artinya pendapatan nasabah memiliki kontribusi pengaruh sebesar $49,3 \%$ terhadap kolektibilitas.

Tabel 8. Hasil Pengujian Koefisien Determinasi Karakter debitur dan Pendapatan nasabah Terhadap Kolektibilitas.

Model Summary

\begin{tabular}{lr|r|r|r} 
Model & R & R Square & Adjusted R Square & Std. Error of the Estimate \\
\hline 1 & $.743^{\mathrm{a}}$ & .552 & .542 & 2.770 \\
\hline a. Predictors: (Constant), Pendapatan Nasabah (X2), Karakter Debitur (X1)
\end{tabular}

Berdasarkan hasil pengujian diperoleh nilai determinasi sebesar 0,552 artinya karakter debitur dan pendapatan nasabah secara simultan memiliki kontribusi pengaruh sebesar $55,2 \%$ terhadap kolektibilitas, sedangkan sisanya sebesar $44,8 \%$ dipengaruhi faktor lain.

\section{d. Uji Hipotesis} Uji hipotesis Parsial (Uji t)

Pengujian hipotesis dengan uji $t$ digunakan untuk mengetahui hipotesis parsial mana yang diterima.

Hipotesis pertama: Terdapat pengaruh yang signifikan karakter debitur terhadap kolektibilitas.

Hipotesis kedua: Terdapat pengaruh yang signifikan antara pendapatan nasabah terhadap kolektibilitas.

Tabel 9. Hasil Uji Hipotesis Karakter debitur Terhadap Kolektibilitas.

\section{Coefficients ${ }^{\mathrm{a}}$}

Unstandardized Coefficients Standardized Coefficients

\begin{tabular}{|c|c|c|c|c|c|}
\hline Model & $\mathrm{B}$ & Std. Error & Beta & $\mathrm{t}$ & Sig. \\
\hline 1 (Constant) & 21.212 & 3.002 & & 7.066 & .000 \\
\hline Karakter debitur (X1) & .666 & .079 & 659 & 8.445 & .000 \\
\hline
\end{tabular}

a. Dependent Variable: Kolektibilitas (Y) 
Berdasarkan hasil pengujian pada tabel di atas, diperoleh nilai $\mathrm{t}$ hitung $>\mathrm{t}$ tabel atau $(8,449>1,986)$, dengan demikian hipotesis pertama Tabel 10. Hasil Uji Hipotesis Pend yang diajukan bahwa terdapat pengaruh yang signifikan atara karakter debitur terhadap kolektibilitas diterima.

\begin{tabular}{|c|c|c|c|c|c|}
\hline \multirow[b]{2}{*}{ Model } & $\begin{array}{r}\text { Coe } \\
\text { Unsta } \\
\text { Coe }\end{array}$ & $\begin{array}{l}\text { icientsa } \\
\text { lardized } \\
\text { cients }\end{array}$ & $\begin{array}{l}\text { Standardized } \\
\text { Coefficients }\end{array}$ & \multirow[b]{2}{*}{$\mathrm{t}$} & \multirow[b]{2}{*}{ Sig. } \\
\hline & B & Std. Error & Beta & & \\
\hline 1 (Constant) & 16.713 & 3.141 & & 5.320 & .000 \\
\hline Pendapatan nasabah (X2) & .782 & .082 & .702 & 9.501 & .000 \\
\hline
\end{tabular}

a. Dependent Variable: Kolektibilitas (Y)

Berdasarkan hasil pengujian pada tabel di atas, diperoleh nilai $\mathrm{t}$ hitung $>\mathrm{t}$ tabel atau $(8,595>1,986)$, dengan demikian hipotesis kedua yang diajukan bahwa terdapat pengaruh yang signifikan atara pendapatan nasabah terhadap kolektibilitas diterima.

Tabel 11. Hasil Uji Hipotesis Karakter debitur da
Kolektibilitas.
ANOVA $^{\text {a }}$

\begin{tabular}{|c|c|c|c|c|c|}
\hline Model & Sum of Squares & $\mathrm{df}$ & Mean Square & $\mathrm{F}$ & Sig. \\
\hline 1 Regression & 869.146 & 2 & 434.573 & 56.629 & $.000^{\mathrm{b}}$ \\
\hline Residual & 706.012 & 92 & 7.674 & & \\
\hline Total & 1575.158 & 94 & & & \\
\hline
\end{tabular}

Berdasarkan hasil pengujian pada tabel di atas, diperoleh nilai $\mathrm{F}$ hitung $>\mathrm{F}$ tabel atau $(56,629>2,700)$, dengan demikian hipotesis ketiga yang diajukan bahwa terdapat pengaruh yang signifikan atara karakter debitur dan pendapatan nasabah terhadap kolektibilitas diterima.

\section{Pembahasan Hasil Penelitian \\ 1. Pengaruh Karakter debitur Terhadap Kolektibilitas}

Karakter debitur berpengaruh signifikan terhadap kolektibilitas dengan korelasi sebesar 0,659 atau memiliki hubungan yang kuat dengan kontribusi pengaruh sebesar 43,4\%. Pengujian hipotesis diperoleh nilai $t$ hitung $>t$ tabel atau $(8,449>1,986)$. Dengan demikian hipotesis pertama yang diajukan bahwa terdapat berpengaruh signifikan antara karakter debitur terhadap kolektibilitas diterima.

\section{Uji Hipotesis Simultan (Uji F)}

Pengujian hipotesis dengan uji $\mathrm{F}$ digunakan untuk mengetahui hipotesis simultan yang mana yang diterima.

Hipotesis ketiga Terdapat pengaruh yang signifikan antara karakter debitur dan pendapatan nasabah terhadap kolektibilitas.

an Pendapatan nasabah Terhadap 
sedangkan sisanya sebesar 44,8\% dipengaruhi faktor lain. Pengujian hipotesis diperoleh nilai $\mathrm{F}$ hitung $>\mathrm{F}$ tabel atau $(56,629>2,700)$. Dengan demikian hipotesis ketiga yang diajukan bahwa terdapat berpengaruh signifikan antara karakter debitur dan pendapatan nasabah terhadap kolektibilitas diterima.

\section{PENUTUP}

\section{Simpulan}

1. Karakter debitur berpengaruh signifikan terhadap kolektibilitas dengan kontribusi pengaruh sebesar 43,4\%. Uji hipotesis diperoleh nilai $\mathrm{t}$ hitung $>\mathrm{t}$ tabel atau $(8,449>1,986)$.

2. Pendapatan nasabah berpengaruh signifikan terhadap kolektibilitas dengan kontribusi pengaruh sebesar 49,3\%. Uji hipotesis diperoleh nilai $\mathrm{t}$ hitung $>\mathrm{t}$ tabel atau $(8,595>1,986)$.

3. Karakter debitur dan pendapatan nasabah berpengaruh signifikan terhadap kolektibilitas dengan kontribusi pengaruh sebesar 55,2\% sedangkan sisanya sebesar $44,8 \%$ dipengaruhi faktor lain. Uji hipotesis diperoleh nilai $\mathrm{F}$ hitung $>\mathrm{F}$ tabel atau $(56,629>2,700)$.

\section{Saran}

Berdasarkan hasil penelitian, maka penulis memberikan saran sebagai berikut:

1. Sebagai pihak lembaga keuangan syariah selayaknya untuk mempertahankan dan meningkatkan prosedur analisis pembiayaan pada aspek karakter debitur agar tidak terjadi penundaan dan kemacetan dalam pengembalian pembiayaan murabahah. Karena dengan berapapun pendapatan yang nasabah peroleh jika memiliki karakter debitur yang baik, maka akan mempunyai kesadaran dalam memenuhi kewajibannya untuk mengembalikan pembiayaan yang telah diberikan.

2. Sebagai tambahan informasi bagi para akademis, bahwa tidak hanya variabel karakter debitur dan pendapatan nasabah yang mempengaruhi tingkat pengembalian pembiayaan murabahah. Dengan demikian hal tersebut dapat dijadikan bahan informasi tambahan untuk diteliti lebih lanjut, apakah berlaku juga untuk lembaga keuangan syariah lainnya.

3. Untuk peneliti selanjutnya diharapkan dapat mengembangkan penelitian dengan menambahkan variabel yang lain dan metode penelitian yang berbeda yang dapat mempengaruhi tingkat pengembalian pembiayaan murabahah.

\section{DAFTAR PUSTAKA}

Alfiani, Rista Maulita. 2015. "Pengaruh Karakteristik Debitur Terhadap Kelancaran Pengembalian Pinjaman Prosedur Pada Koperasi Pegawai Republik Indonesia (KPRI) Bahagia Jaya, Gubeng Surabaya", skripsi, Universitas Islam Negeri Sunan Ampel.

Antonio, Syafi'i. 2001. "Bank Syariah dari teori ke praktik", Jakarta: Gema Insani Press

Astuti, Widya. 2015. "Pengaruh Karakteristik individu, usaha, dan pembiayaan terhadap tingkat pengembalian pembiayaan oleh UKM pada BMT Ummat Sejahtera", skripsi, Universiatas Islam Negeri Sunan Ampel Surabaya.

Desyani, Arwinta Nur. 2013. "Analisis Pengaruh Karakter Dan Kondisi Ekonomi Nasabah Terhadap Pembiayaan Bermasalah", skripsi, Universitas Institut Agama Islam Negeri Walisongo Semarang.

Ghozali. 2016. "Aplikasi Analisis Multivariete dengan program SPSS. Semarang: Badan Penerbit Universitas Dipenogoro.

Haque, M. G., Nurjaya, N., Affandi, A., Erlangga, H., \& Sunarsi, D. (2021). Micro Financial Sharia Non-bank Strategic Analysis: a Study at BMT Beringharjo, Yogyakarta. Budapest International Research and Critics Institute (BIRCI-Journal): Humanities and Social Sciences, 4(2), 1677-1686.

Hidayat. 2015."Mekanisme Penanganan Pembiayaan Murabahah bermasalah terhadap kinerja BMT Al Azkar Pamulang". Skripsi, UniversitasPamulang.

Ikatan Bankir Indonesia. 2015. "Manajemen Resiko 1", Jakarta: PT Gramedia Pustaka Utama.

Ismail. 2011. "Perbankan Syariah", Jakarta : Kencana

Kasmir. 2013. "Bank dan lembaga Keuangan Linnya”, Jakarta: Rajawali Pers 
Lutfi, A. M., Erlangga, H., Nurjaya, N., Priadana, S., \& Dwiwarman, D. A. (2021). Pengaruh Capital Adequacy Ratio Dan Bopo Ratio Terhadap Return On Asset Pada Pt. Bank Muamalat Indonesia, Tbk Periode 2010-2019. Jurnal Ekonomi Efektif, 3(3).

Muljono, Djoko. 2015. "Buku Pintar Akuntansi-Perbankan Dan Lembaga Keuangan Syariah". Andi

Najibullah, et al. (2021). Pengaruh non Performing Financing dan Financing to Deposit Ratio terhadap Pembiayaan pada Bank DKI Syariah. Jurnal Neraca Peradaban. Volume 1. Issue1. Pages 485

Muslimat, A., Muhsin, H., Wahid, H. A., Yulistiana, I., Sunarsi, D., Dewi, K., ... \& Ilham, D. (2021). Develop Technology Based Multimedia For Indonesian Teachers. Journal of Contemporary Issues in Business and Government, 27(1), 1871-1882.

Purwanti, Y. (2021). The Influence Of Digital Marketing \& Innovasion On The School Performance. Turkish Journal of Computer and Mathematics Education (TURCOMAT), 12(7), 118-127.

Muslimat, A. (2021). Masa Depan Kampus Merdeka \& Merdeka Belajar: Sebuah Bunga Rampai Dosen. Bintang Visitama Publisher.

Nurjaya, N., Affandi, A., Ilham, D., Jasmani, J., \& Sunarsi, D. (2021). Pengaruh Kompetensi Sumber Daya Manusia Dan Kemampuan Pemanfaatan Teknologi Terhadap Kinerja Aparatur Desa Pada Kantor Kepala Desa Di Kabupaten Gunungkidul, Yogyakarta. JENIUS (Jurnal Ilmiah Manajemen Sumber Daya Manusia), 4(3), 332-346.

Nurjaya, et al (2021). Pengaruh Liquiditas dan Profitabilitas terhadap Return Saham: Studi Empiris Pada Perusahaan Real Estate Dan Property Yang Terdaftar Di Bursa Efek Indonesia Tahun 2017-2019. Jurnal Tadbir Peradaban Volume 1. Issue.1. Pages 6068.

Pujiati, H., Sunarsi, D., Affandi, A., \& Anggraeni, N. (2021). Effect of ISO 9001: 2015 Quality Management Implementation in Education on School Performance. Journal of Contemporary
Issues in Business and Government, 27(1), 1848-1855.

Purwasih, Desy. 2015. "Analisis Pengendalian Internal atas Penyaluran Pembiayaan Murabahah pada BPRS As-Salaam Cabang Ciputat", skripsi, Universitas Pmualang.

Putra, Yusuf Kurniawan. 2013. "Faktor-Faktor yang Mempengaruhi Pengembalian Pembiayaan Murabahah PT Bank BNI Syariah Kantor Cabang Pembantu Mikro Bogor". Skripsi, Universitas Institut Pertanian Bogor.

Rachmat, Muhammad Zeni. 2011. "Analisis Faktor-Faktor Yang Mempengaruhi Pengembalian Pembiayaan Agribisnis pada Bank Umum Syariah". Skripsi Universitas Institut Pertanian Bogor.

Rahayu, Tri Andina. 2016. "Analisis FaktorFaktor yang Mempengaruhi Kelancaran Pengembalian Pembiayaan Murabahah pada usaha Mikro, Kecil dan Menengah (UMKM) di BMT Taruna Sejahtera. Jurnal Vol.7, Universitas IAIN Salatiga.

Salam, A., Hikmat, I., Haquei, F., \& Badariah, E. (2021). The Influence of Share Ownership, Funding Decisions, Csr and Financial Performance of Food Industry. Annals of the Romanian Society for Cell Biology, 12698-12710.

Salman, Kautsar Riza. 2012."Akuntansi Perbankan Syariah berbasis PSAK Syariah".Padang-Indonesia:@kademia Permata.

Sjahdeini, Sutan Remy. 2010. "Perbankan Syariah: Produk-produk dan aspekaspek hukumnya", Jakarta: PT Jayakarta Agung offset.

Soemitra, Andri. 2010. "Bank dan Lembaga Keuangan Syariah". Jakarta: Kencana

Sudarsono, Heri. 2015. "Bank dan Lembaga Keuangan Syariah: Deskripsi dan Ilustrasi", Yogyakarta: Ekonisia.

Sugiyono. 2013. "Metode Penelitian Kombinasi", Bandung: Alfabeta.

Wiroso. 2009. "Produk Perbankan Syariah". Jakarta: LPFE Usakti

Yaya, Rizal dkk. 2009. "Akuntansi Perbankan Syariah: Teori dan Prakti Kontemporer", Jakarta: Salemba Empat.

Yusuf, Muhammad. 2015 "Analisis Karakter Nasabah dalam Meminimalisir Risiko Pembiayaan Murabahah". Tugas Akhir, Universitas UIN Walisongo Semarang 